\title{
PSYCHOGEOGRAPHY OF KUALA LUMPUR IN NASSURY IBRAHIM'S SELECTED POEMS
}

\section{(Psikogeografi Kuala Lumpur dalam Puisi Nasurry Ibrahim)}

\author{
Ruzy Suliza Hashim
}

ruzy@ukm.edu.my

\author{
Fatin Nur Syahirah Faizal \\ a137354fatin@gmail.com
}

Sustainability of Language Sciences Research, Faculty of Social Sciences and Humanities, Universiti Kebangsaan Malaysia, 43600 Bangi, Selangor, Malaysia.

\begin{abstract}
The strong connection between people and place provides fodder for literary producers to create their works. In his anthology of poems Ruang Kota, Nassury Ibrahim draws upon Kuala Lumpur as the place that allows him to delve into the study of self and other people. Using psychogeography as an analytical tool, this article examines how Kuala Lumpur affects the mental states and behaviors of the people living in the heart of the urban city. Nassury's poems deal with many aspects of life which include poverty, pollution and humanity. Other than his experiences, the poet uses the landscape of the city to express his own perspectives and feelings towards Kuala Lumpur. Based on the analysis, Kuala Lumpur is portrayed as a city that has developed materially but its dwellers benevolence and compassion have lessened greatly. His poems highlight urban poverty and poor urban planning in Kuala Lumpur which have led to poor quality of life in this cosmopolitan city.
\end{abstract}

Keywords: psychogeography, urban poor, Kuala Lumpur

\section{Abstrak}

Hubungan erat antara sebuah masyarakat dengan tempat menjadi sumber inspirasi untuk pengkarya sastera menghasilkan karya. Dalam antologi Ruang Kota, Nassury Ibrahim memberikan tumpuan terhadap Kuala Lumpur 
sebagai lokasi yang menyerlahkan dirinya sebagai pengkaji kendiri dan masyarakat sekeliling. Dengan menggunakan psikogeografi sebagai lensa kritikan, makalah ini mengkaji kesan pembangunan Kuala Lumpur terhadap keadaan mental dan tingkah laku masyarakat yang tinggal di kota raya ini. Puisi Nassury memaparkan pelbagai aspek dalam kehidupan termasuklah kemiskinan, pencemaran dan kemanusiaan. Selain pengalaman beliau, Nassury telah menggunakan landskap kota tersebut untuk menitipkan perspektif dan perasaannya terhadap Kuala Lumpur. Kuala Lumpur digambarkan sebagai sebuah kota yang telah membangun secara material, akan tetapi sifat kebaikan dan belas kasihan penduduknya telah berkurangan dengan begitu ketara sekali. Puisi Nassury menunjukkan kesempitan hidup dan kualiti kehidupan yang rendah akibat kelemahan perancangan bandar yang memberikan kesan buruk kepada penduduk bandar kosmopolitan ini.

Kata kunci: psikogeografi, kemiskinan bandar, Kuala Lumpur

\section{INTRODUCTION}

As the capital city of Malaysia, Kuala Lumpur is known to have had a long history of development - from the small tin mine activities along Sungai Kelang to a city teemed with skyscrapers, a place that is home to millions of people from different ethnic groups. These rapid developments showed a modernized and progressive city with massive changes of physical infrastructure, residential areas, and other developments (Nor Hanisah M. H. et al., 2009). However, the intensification of urban sprawl within Kuala Lumpur has led to other issues faced by urban residents of the city. In relation to this, the article examines the issues faced by the people, reflected in the selected Malay poems from Nassury Ibrahim's anthology of poems Ruang Kota.

In Ruang Kota, Nassury Ibrahim's works provide an insight into the life of the urban people in Kuala Lumpur. His poems in Ruang Kota are a collection of his writings from the 1980s until in the early 2000s but were mostly written in the 1990s. As Nassury says in his preface, the poems were based on his experiences, perceptions and hopes towards the city (ix). Nassury Ibrahim was born in Kelantan and moved to Kuala Lumpur in 1990 to become a teacher. But his poem was first written in 1980, during his visits to Kuala Lumpur as an outsider. Therefore, it can be said that his anthology was written from two different lenses; as a traveller and resident. Claiming himself as "penghuni kota kelas ketiga" (xi) which means a third class citizen in the city, most of his poems reflect the life of the urban poor, the class of urban residents who are mostly affected by Kuala Lumpur's rapid 
development. Other than that, he touches on environmental and spiritual issues that are crucial in ascertaining that the city's decadent lifestyle does not corrupt one's mind and soul. The perspective on the urban poor is apparent even from the visual representation of the book cover. The image of Kuala Lumpur is inverted underneath the image of the slums, which brings to an interpretation that they are correlated as both images reflect each other. This leads to another meaning that poverty and urbanity live side by side.

\section{KUALA LUMPUR AND URBANIZATION}

According to Jamalunlaili (2012), Malaysia officially became an urban nation in 1991 when the population in urban areas increased up to fifty percent. From his study, a closer examination of the data found that most of the population and built up areas that showed growth since 1980 occurred in areas outside the core city boundaries namely Kuala Lumpur, Penang and Johor Bahru. At the same time, globalization and economic competitiveness among nations and cities have caused governments in Southeast Asia, including Malaysia, to focus economic development to existing metropolitan areas in order to make cities become economically more competitive. The inclusion of Greater Kuala Lumpur as one of the key economic areas of Malaysia Economic Transformation Program (ETP) highlights the importance of cities as economic growth engine (The World Bank, 2011).

Although Malaysia has established itself as an urban nation, according to the study conducted by Syafiee (2004), Kuala Lumpur experienced population decline from 156981 people in 1980 to 128721 people in 2000. This drop was partly due to the shortage of affordable housing. People started to move to the suburbs and outlying towns and commute daily because houses are cheaper outside of Kuala Lumpur, and more efficient transport such as the commuter trains and Light Rail Transport (LRT) have influenced city dwellers to live further away. With the rise of suburbanization, Kuala Lumpur as the city centre had evolved into employment and entertainment centres only. Syafiee (2004) further observed that:

The changing city dwellers lifestyle and further deterioration of environment in the city are also contributing factors for more people to move out to the suburbs for better living condition at the affordable price.

Nassury Ibrahim was one of the urban residents who experienced the rapid development of Kuala Lumpur in 1990s. Therefore, many of his poems 
in Ruang Kota reflect his feelings and hopes for a better living condition in the city at that time. He represents the urban poor community who wants a better life in the city, not only for their generation but also for the future ones.

\section{PSYCHOGEOGRAPHY}

This article appropriates psychogeography as a tool to analyse the significance of Kuala Lumpur that was used in the anthology. Psychogeography, coined by Guy Debord, is the study of psychology and geography which provides a lens to see how an urban city affects the acts and behaviours of its people. According to Debord's definition, psychogeography is "The study of the specific effects of the geographical environment, consciously organised or not, on the emotions and behaviour of individuals" (in Coverley 2006:10). In broad terms, psychogeography is the point at which psychology and geography collide, a means of exploring the behavioural impact of urban place.

In Ruang Kota, the word kota which means city is present in almost all of the poems title. The word kota is associated with the symbolic importance of a place as a repository for emotions and relationships that gives meaning and purpose to life and reflects the sense of belonging. The poet, Nassury Ibrahim, acts as the "flâneur" which means "roamer" or "wanderer", in order to capture the essence of the city for his writing. The term was invented by Charles Baudelaire and was a key figure in late 19th century and early 20th century decadent literary movement. According to Seal (2013), a "flâneur" is a gentleman who strolls the city in order to experience it, as a detached, placid sceptical observer. He is a passive figure; he observes the dynamics of the city from a disengaged point of view. Baudelaire (1995:12) further characterises the "flâneur":

you must allow me to call "modernity"; He makes it his business to extract from fashion whatever element it may contain of poetry within history to distil the eternal from the transitory ... by "modernity" I mean the ephemeral, the fugitive, the contingent, the half of art whose other half is the eternal and the immutable.

Baudelaire's statement emphasises the role of the flâneur as a person who strolls the streets; he is both the observer and participant. Nassury takes on this responsibility and demonstrates how space, time and sociality can produce poems that portray lived realities of city dwellers. 
In theory of the derive, Debord in 1955 defines the concept of the dérive which he explicitly defines as opposed to "different from the classic notions of journey or stroll". The dérive is "a technique of rapid passage through varied ambiances" that "involves playful-constructive behaviour and awareness of psychogeographical effects" (in Knabb, 1995:50). The participants of a dérive must "let themselves be drawn by the attractions of the terrain and the encounters they find there". Debord explains:

... dérive one or more persons during a certain period drop their usual motives for movement and action, their relations, their work and leisure activities, and let themselves be drawn by the attractions of the terrain and the encounters they find there ... But the dérive includes both this letting go and its necessary contradiction: the domination of psychogeographical variations by the knowledge and calculation of their possibilities.

(in Knabb, 1995:50)

Although it is not stated by Nassury that he had adopted the technique of dérive or acted as the "flâneur", by appropriating from the lens of psychogeography, it can be said that he was indeed Baudelaire's 'flâneur', as he engaged in dérive to write his poetry:

As a guest, I always asked about the routes or certain locations ... because of that, I love to wander around by foot because walking has helped me understand the attitude of the people and the environment of Kuala Lumpur. I would walk from Pudu Raya to Chow Kit, or to Masjid India area, or to the National Museum, in fact to Dewan Bahasa dan Pustaka too. All of these experiences are materials that I draw on when I was writing the poems.

(xi)

Nassury Ibrahim's dérive is contemporary urban exploring. He explored the city surroundings freely by being conscious of his surroundings and allowed himself to be drawn by the attractions of the terrain and the encounters he found along the way.

\section{CONCEPTUAL FRAMEWORK}

Literary psychogeography developed by Ross (2013) is appropriated in this article to analyse the selected Malay poems as the corpus of this research. According to Ross (2013:6) in Debord's definition, the "effects" of the "environment" on "individuals" is on both their "behavior," or outer actions, 
and their inner "emotions." In adapting psychogeography to literary theory, Ross (2013) highlighted that:

For this reason psychogeography as a literary theory, though it begins in the physical environment, is not limited to the mundane, but includes the psychological, including the mind in all its creativity. The physicality of the conception of psychogeographical experience does not limit, but provides a framework, it might be said, for the subjective

This means that the place used in the narration is not just a mere setting for the character but also influences a particular part of a city or landscape on the human mind, or a person's projection of inner feelings or moods onto the outer environment. Literary psychogeography acts as a tool that does not limit to classical narratology and helps writers to explore the significance of geographic location, setting, and spatiality for narrative (Ross, 2013). As stated by Lang (1994:25) "Many writers have been successful in evoking a sense of place. Perhaps they have been more successful than architects, because the readers can provide their own images for the physical form." Hence, the use of literary psychogeography to analyse Nassury's poems is novel because it sheds insights into the psyche of the poet as he interacts with the cosmopolitan location.

\section{MAPPING THE CITY}

Literary psychogeography will be used as an analytical tool to assist with the mapping. The mapping is based on place settings mentioned by Nassury in his anthology. Ross (2013) suggested three key items related with psychogeography in literary work that comprise of setting, point of view, and language and the creation of narrative. He believes that these keys are essential when psychogeography is applied as an analytical tool to dissect the literary production.

The mapping will be divided accordingly into two parts; the places where the writer used to live from the year 1990 to 2003, and his experience walking around the city (see Figure 1(a) and 1(b)).

Based on the mapping, the writer used to live in many parts of Kuala Lumpur which include Gombak, Petaling Jaya, Jalan Klang Lama, Pantai Dalam, Sentul, Jalan Haji Abdullah Hukum and Bangsar. In his poems, "Slums Luck" and "In the House of the Slums", he highlights both the "beautiful" 


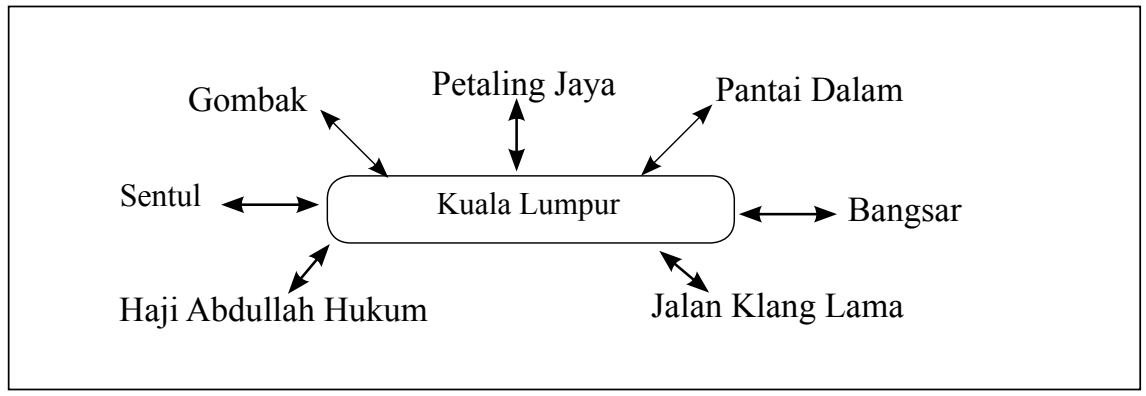

Figure 1 (a) Mapping the writer's previous residence in Kuala Lumpur.

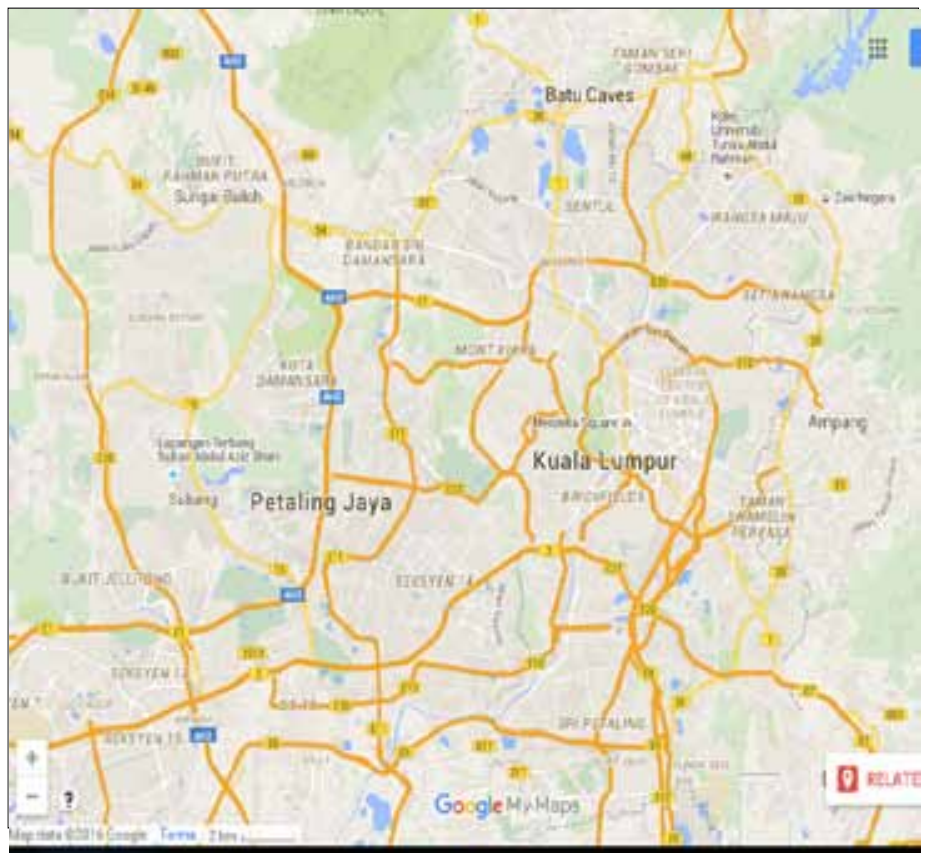

Figure 1 (b) Mapping the writer's previous residence in Kuala Lumpur.

and painful side living in low cost flats. In "Slums Luck" (p. 10) the writer seems to cherish the fact that these low cost flats had provided shelter to him and his family, gave him ideas for his writing and hopes not only for him but the future of his children. 
That which gives the ground to the home, is the slums

That which gives the home a bed to dream, is the slums That which gives the taste of dreams, is the slums

(Nasurry, 2015:10)

In the first three lines of the poem, the writer shows gratitude of the flat that had given him and his family a place to stay in Kuala Lumpur. Although his home is basic, it provides him shelter from the elements. It is here that he is motivated to dream of better things. As shown in the following lines, despite the lack of luxury, he is inspired to write beautiful poetry-words which are borne out of poverty and simplicity of life:

That which gives love, a crown of happiness, is the slums That which gives happiness and hope, is the slums

"May this slums luck, no children are in the slums again."

(Nasurry, 2015:10)

His dwelling is also the place where the love in his own household blooms. However, destitution should not be extended to his future generation, and he prays for a better life for them. But living in the slum area has its downside. "In the House of the Slums" (p. 11), he reflects on its dark side:

In this house of the slums, the fragrance from the drains and melodious sound from the machines, cancer and leukaemia, asthma and tuberculosis, dash towards us.

The writer uses oxymoron in the poem to describe the pollutions he faced. The phrase "fragrance from the drains" and "melodious sound from the machines" illustrate clearly the pong and din in his neighbourhood. In close contact with diseases, life in the city seems destructive:

In this house of the slums, we are struggling in between

The desires that creep freely and the capability

That being blocked, the demand and mechanism

The price that crosses the curve at the graph of suffers.

(Nasurry, 2015:11)

The poor city dwellers find difficulty to make ends meet as they struggle "in between/ the desires that creep freely" (page 11). The speaker dwells 


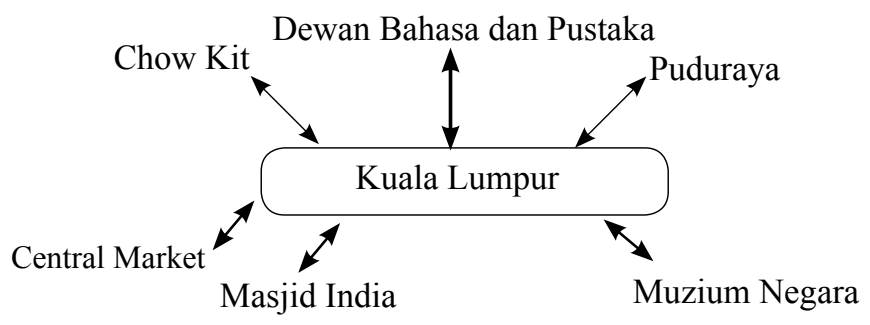

Figure 2 (a) Mapping places in the poems.

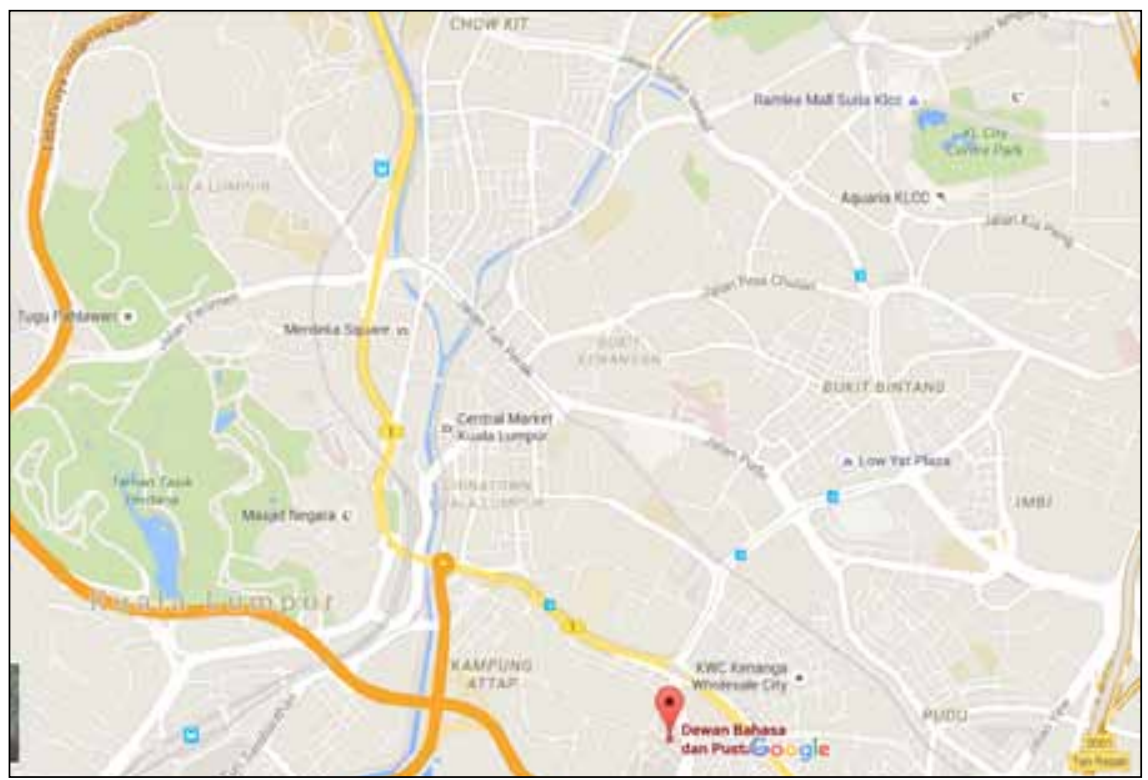

Figure 2 (b) Mapping locations in the poems.

on his dilemma; he hates the poverty in the city and longs to return to his kampong. But the inability to do so remains ambivalent; the speaker is trapped in his condition.

The speaker's predicament can be corroborated by social studies on urban poverty. According to Nor Rashidah et al. (2012), housing is not only a physical shelter but also plays a significant role that affects a person's 
physical, mental, and emotional health conditions. Housing condition and its surrounding environment of the housing area influence its dwellers. The study found that the housing conditions of the urban poor in Malaysia are lacking all these aspects such as limited space, insufficient natural light, leakages, windows and floors in bad condition, mouldy walls and insufficient recreational area or garden. Although the poems were written during the writer's time living in the squatters (from 1990 to 2003), it can be said that the predicaments he raised in the poems are still conspicuously experienced by the urban poor [see Figure 2(a) and 2(b)].

This map shows the places which the writer uses that are situated in the heart of Kuala Lumpur which are later "projected" in the poems. He raises issues such as pollution, faith and morality. In "The Sigh of the City" (p. 18), he talks about the mundane life as the working class in the city that include the pollutions and road jams he has to face.

I'm lonely, says the city

Every day I'm here alone

In the middle of the machinery space

I'm in pain, says the city

Every day my heart

Stumbles upon these machines

My lungs

Poisoned by the exhaust

the daily affairs

That scratch my body

consume my youth

Every day

Being hemmed in by the coldness of equipment and machines, the speaker longs for human warmth. He is engulfed in impure air in the place he works in, and as he commutes from home to work. The noisy sounds from the machines assault his ears. The speaker does not seem to take pleasure in his very existence; everyday is a chore. At dawn, Muslims would pray for blessings of the Creator. The city-dweller greets another dawn spiritlessly as shown in the lines below:

The second the dawn opens

The door of rizq 
I crawl out

Catching the dream, says the city

The second the dusk releases the anchor

I'm still crawling

Lost in my own body

(Nassury, 2015:18)

Life for him holds no assurance of a better tomorrow. The dream that the city promises remains unfulfilled. The speaker's mood is desolate; he seems inclined to think that the future remains bleak. The city of hope has become the city of misfortune.

In "The Air of the City" (p. 12), Nassury speaks about the quality of air in the city which is hazardous and harmful to its inhabitants:

May be whatever you breathe in, they are the fine solid molecules

May be the fine solid molecules are a mass of dust

The quality of air deteriorates due to construction work and increasing number of vehicles that emit carbon dioxide. These dangerous particles lead to health problems such as asthma and cancer: "May be the dust lodged in you plants asthma and cancer/May be the asthma and cancer propagate within you". According to the article "How Air Pollution Contributes to Lung Disease in Physicians for Social Responsibility report" (2009), exposure to pollution can trigger new cases of asthma and provokes development or progression of chronic illnesses including lung cancer, chronic obstructive pulmonary disease, and emphysema. Air pollution adds misery to city dwellers who are already grappling with poverty; they are imperilled by the environment. Their predicament is accentuated with the final couplet, "what you inhale is not sweet fragrant air/what you inhale is the filth of affliction".

His perception on the city includes the social life of its dwellers. In "Night in the City" (p. 15), he highlights a city that does not sleep:

Night in the city

Very sweet and seductive

at the quiet alleys

at the shopping malls

Seduction here takes on an ambivalent tone. On the one hand, "the quiet alleys" refers to solitude and perhaps privacy to lovers; on the other hand, 
shopping malls provide temporary respite from their daily toil. Kuala Lumpur is known for luxurious and mega shopping malls such as KLCC, Pavilion and One Utama, and the places are always bustling with customers. The speaker however cautions the inhabitants of the seductive hold of the city by saying that "night in the city/is a test from God/of the citizens' faith." Those who are carried away with promiscuous way of life will lose their purpose of life and become spiritually poor.

From this poem, we can relate to the spiritual aspect of a person that is reflected in "In This City Space" (p. 24). The writer feels that the people have lost their way in navigating their own lives in the urban city. The lines "Day by day/ living in this city space/ we feel it/ getting far from You" depict his sense of loss. Hence, city life attributes to spiritual emptiness. Nassury expands on the spiritual aspect in "No Human Lives Here" (p. 32) where he states that city dwellers are emotionless except for him, as in the first line of the poem suggests; "Here is no human/ but me". These lines stress the loneliness of the speaker. There are people around him but their friendship is impermanent: "Sometimes yes sometimes no sometimes a friend sometimes a foe" explains clearly the absence of true friendship, sincerity and loyalty. The city seems devoid of values.

In "Taking Notes" (p. 41), the writer reflects how the city has "turned" him into a slave as the lines "Yes, Kuala Lumpur, yes yes/ you are the King of Lust/I'm your slave". At first, he states that the city is far beyond his reach, from the lines "You are too handsome/for me to love you/ the face says /you're too deep/ for me to swim into, says my strength". But later, he is defeated by the city as it overwhelms his state of being. His suffering, the consequence of living in the city, reflects the agony of the metropolitan. Nassury's use of contrast to depict the tension of the speaker as he grapples with varying emotions: he wants to feel affection for Kuala Lumpur; yet he is overcome by its challenges. It is a paradise but the speaker has to be wary of the "flowers" in this garden. Hence, Nassury illustrates the pressure of the speaker as he continually psyches himself to remain strong in the face of various challenges living in Kuala Lumpur.

Nevertheless, Nassury provides ways in which the city can become beautiful and habitable to its dwellers. In the poem, "Would It Be Great" (p. 8), he suggests a sustainable design that is eco-friendly: "A city decorated with / the chirping of magpies not crows/ a city that is overgrown with/ variety of trees not stones". Development of buildings must be accompanied by spaces which include greenery. There should be adequate waste disposal system to 
encourage clean living. He wishes for a "city that is habited with/ human souls not robots indicate that he also hopes for a city that filled with humans with souls rather than human robots". He hopes for a city that fosters its inhabitants to be sincere, polite, kind, generous as shown in the following lines:

A city that makes good its promises

A city that is gracious

A city that is compassionate

A city that is benevolent

A city that stands on its feet

The hope reflected in "Would It Be Great" is also similar to "Dream City" (p. 17). In this poem, the speaker longs for the city dwellers to be more loving and refined. To achieve this state of being, he suggests for them to harness on their spirituality and strengthen their relationship with God as what proposed: "A city that moves/On His rails". In the lines "A city that is liberated/ heart and eyes", the speaker wants the people to be freed from vice:

A city teeming with

Beautiful dwellers

A city tenanted by

Modest courtesy

A city that syncs

On His rails

A city that is liberated

Other than relationship between people and God, the writer wants the people to nurture their relationship with the environment; knowing to appreciate and love other God's creations (p. 17).

A city that loves

Humans, animals and plants

He also longs for the city where its people are physically and spiritually healthy, and they remember their roots, customs and beliefs despite facing rapid modernization (p. 17):

A city that is well and unsullied

In its conscience and form

A city that steadily stands

On its traditional roots 
Despite his perception and hope towards the city, Nassury reflects his gratitude in the poem "Indeed" (p. 19).

I've become poor in this space

In the space where desires creep freely

In the space where capability can be blocked

"O the Most Richest, $\mathrm{O}$ the Giver I am grateful

To You for this poverty

I've known true wealth."

He indicates that Kuala Lumpur is not an easy place to live and survive because people have difficulty making ends meet. However, the speaker realises that the hardship of life he faces has helped him to understand that true happiness in life is not here, but in the Hereafter. Therefore, he feels grateful for being able to live and learn the great value of life through the hardships he faces.

For Nassury, the way he sees Kuala Lumpur is not just a mere developed city but a city that has a soul like humans. As stated by him in the preface (p. xii); "Of course, a city like human instinct, too, does not want any depravity to blacken her". With this, he ends the anthology with a poem entitled "The City Whispers", a poem that represents the city's hope for the urban dwellers.

Mister, please look at me

With an open heart

Don't look at me

With reprisal

(Nassury, 2015:46)

In the verse above, the city "pleads" to the people, wanting them to think what is best for the city, not allowing greed to take over. The speaker fears that human "lust" leads to deterioration of the metropolis.

Mister, please look at me

With an open heart

I want to experience

The neighbourliness of kampong life.

(Nassury, 2015:46) 


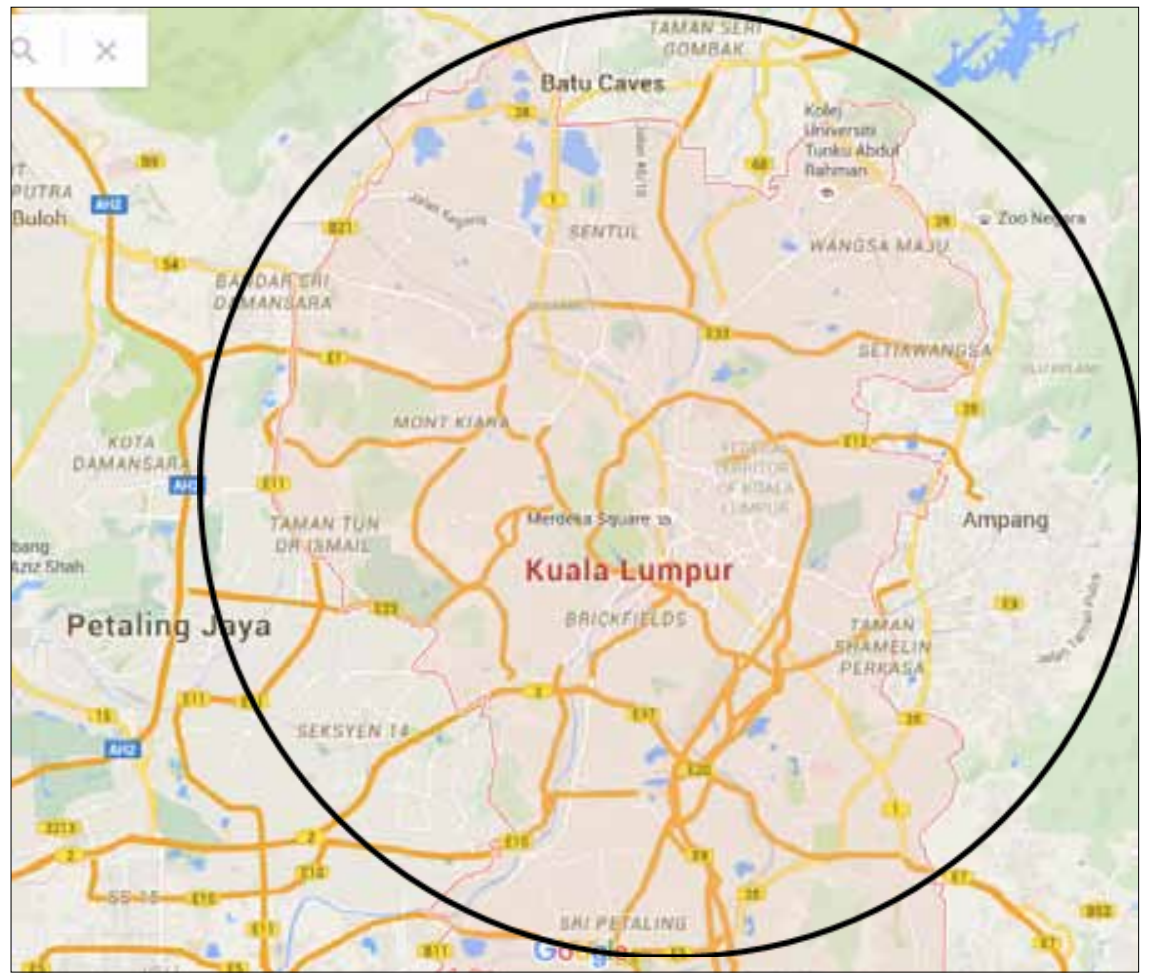

Figure 3 The places that have inspired Nassury to produce poems in the anthology of Ruang Kota.

The last verse also shows an irony; the fact that the great city of Kuala Lumpur is the most developed city in Malaysia, yet, its dwellers long for village life - an environment where simplicity, unpretentiousness, and friendship abound.

Figure 3 is the composite mapping of the places that have inspired Nassury to produce poems in the anthology of Ruang Kota. The poet has gone on physical and mental journey of many parts of Kuala Lumpur, making him well versed with the city. Through his poems, Nassury raised his concerns on the issues that revolve around the society. Through his speaker, a kampong man who has migrated to the city due to employment opportunity, he highlights various ills that afflict both the metropolis and its inhabitants such as urban poverty, unsustainable development, hostile neighbours, spiritual paucity of its people. Through his interaction with various sites in Kuala Lumpur, 
he critiques the way in which the city has developed. Its modernization is supposed to raise the standard of its people, yet Nassury shows how people have become less happy and the quality of life is absent. His poetry reflects precedes Mc Gee's thoughts on "The Urbanisation Transition in Malaysia in the Twenty-First Century" (2011) who states that:

Perhaps, it is now time for Malaysia to shift from an obsession with "developmentalism" to focus on what kind of society they want to become. One that is more in tune with the contemporary urban reality and developed state.

(Mc Gee, 2011:118)

Urban areas create social, spatial and environmental problems. Nassury poems highlight some of these problems to the readers. The "flâneur" brings to life pressing issues that afflict city dwellers. The realities facing them are not just imagined by Nassury; they are substantiated by scholarly studies by sociologists and urban planners.

\section{CONCLUSION}

Nassury Ibrahim's poems are unique because they are borne out of experience as a "flâneur". Psychogeography gives a different view in analysing the poems as the settings in Kuala Lumpur are shown to be significant in providing insights into the moods and thoughts of an urban dweller. While the city is not ideal, it is a place for the poet to survive. Despite the contradictions, Ruang Kota shows that the poet is attached to Kuala Lumpur. He longs for the city to assimilate kampong values of neighbourliness and sustainable living and seems to suggest that those values, if embraced by the urbanites, will make the city a pleasant place to live in.

Urban planners do not often explore views from literary producers. There is much that they can learn from Nassury's poetry. What strategies can be put in place to assist those who barely make ends meet? What can be done to make their living space more habitable and conducive? What programmes can be planned to encourage integration between neighbours? These are some issues which Nassury has highlighted in his poems. They are not imagined problems; they are the stark realities of many city dwellers. The environment of a locality contributes to the well-being of its residents. As Nassury reminds us: 
Of course each experience triggers hope and optimism. I, too, am hopeful and optimistic. I have put together these poems to record the heart and soul of my dream city. I realise that a city's soul is very much like a human soul; I do not want a city with a dark soul because it will influence on me.

(Nassury, 2015:xii)

\section{REFERENCES}

Anon, 2009. How Air Pollution Contributes to Lung Disease. Physicians for Social Responsibility in http://www.psr.org/assets/pdfs/air-pollution-effects-respiratory. pdf [1 April 2016].

Baudelaire, Charles, 1995. The Painter of Modern Life and Other Essays. Phaidon

Press Ltd. London.

Coverley, M., 2006. Psychogeography. Harpenden: Pocket Essentials.

Jamalunlaili Abdullah, 2012. "City Competitiveness and Urban Sprawl: Their Implications to Socio-economic and Cultural Life in Malaysian Cities". AcEBs 2012 Bangkok ASEAN Conference on Environment-Behaviour Studies, Bangkok, Thailand, pp. 20-29, 16-18 July 2012.

Knabb, Ken, ed., 1995. Situationist International Anthology. Berkley: Bureau of Public Secrets.

Lang, J., 1994. Urban design: The American Experience. John Wiley \& Sons, New York.

Mc Gee, Terry, "The Urbanisation Transition in Malaysia in the Twenty-First Century" in Akademika 81:2, pp.109 -21, 2011.

Nassury Ibrahim, 2009. Biodata. http://nassuryibrahim.blogspot.my/p/mengenaisaya_07.html [20 March 2016].

Nassury Ibrahim, 2015. Kumpulan Puisi Ruang Kota. Kuala Lumpur: Institut Terjemahan Buku Malaysia.

Norsidah Ujang, 2009. "Place Attachment and Continuity of Urban Place Identity". 1st National Conference on Environment-Behaviour Studies Faculty of Architecture, Planning \& Surveying, Universiti Teknologi MARA, Shah Alam, Selangor, Malaysia, , pp. 156-67, 14-15 November 2009.

Nor Hanisah M. H., J. D. Hitchmough, A. Muda, 2009. "The Perception of Kuala Lumpur Publics' on Tree Retention and Urban Development". 1st National Conference on Environment-Behaviour Studies, Faculty of Architecture, Planning \& Surveying, Universiti Teknologi MARA, Shah Alam, Selangor, Malaysia, pp. 215 -26, 14-15 November 2009.

Nor Rashidah Zainal, Gurmit Kaur, Nor 'Aisah Ahmad, Jamaliah Mhd. Khalili, 2012. Housing Conditions and Quality of Life of the Urban Poor in Malaysia. AcEBs 2012 Bangkok ASEAN Conference on Environment-Behaviour Studies, Bangkok, Thailand, pp. 827 -38, 16-18 July 2012. 
MALAY LITERATURE VOLUME 29 NUMBER 2 DECEMBER 2016

Ross CK, 2013. "Developing a Method of Literary Psychogeography in Postmodern Fictions of Detection: Paul Auster's the New York Trilogy and Martin Amis's London Fields". PhD dissertation.Texas A\&M University-Commerce.

Syafiee Shuid, 2004. "Urbanization and Housing in Kuala Lumpur City Centre: Issues and Future Challenges" in 19th Earoph World Planning and Housing Congress, pp. 1 - 14, 2004.

The World Bank, 2011. Malaysia Economic Monitor: Smart Cities. Bangkok The World Bank.

Received: 8 November 2016

Accepted: 21 November 2016 